\title{
A Study on Housing Loan Evolution and Performance in India
}

\author{
Prof. Rekha. D. M11, Gangamma. S. E \\ ${ }^{1}$ Assistant Professor, ${ }^{2}$ Studunt \\ 1,2SJR PU College for Women, Bangalore, Karnataka, India
}

\begin{abstract}
How to cite this paper: Prof. Rekha. D. M | Gangamma. S. E "A Study on Housing Loan Evolution and Performance in India" Published in International Journal of Trend in Scientific Research and Development (ijtsrd), ISSN: 24566470, Volume-3 | Issue-4, June 2019, pp.702-706, URL: https://www.ijtsrd.c om/papers/ijtsrd23 883.pdf

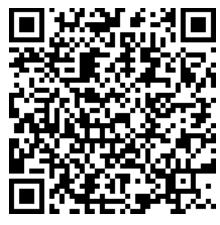
IITSRD23883
\end{abstract}

Copyright (C) 2019 by author(s) and International Journal of Trend in Scientific Research and Development Journal. This is an Open Access article distributed under the terms of the Creative Commons

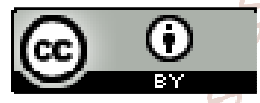
Attribution License (CC BY 4.0) (http://creativecommons.org/licenses/ by $/ 4.0$ )

\section{INTRODUCTION}

Housing is a significant part and a proportion of financial status of the general population. It is viewed as a basic part regarding approach activities and meditations. An enormous part of our populace is as yet missing legitimate lodging office. The lodging issue in India is an annoying issue both in the country and urban regions. One of the primary reasons of the issue of lodging deficiency is its size of populace. It is said that one among the each six people on the planet is an Indian. India stands second among the worlds to a great extent populated nation

\section{REVIEW OF LITERATURE}

According to Bandyopadhyay Arindam and Saha Asish (2011), in their article studied they focused that the importance of borrower-specific characteristics as well as local situation factors in determining the demand prospect as well as the risk of credit loss on residential housing loan repayment behaviour in India. They used 13,487 housing loan accounts (sanctioned from 1993-2007) data from Banks and Housing Finance Cos (HFCs) in India. This paper made an attempt to find out the crucial factors that drive demand for housing and its correlation with borrower characteristics by using a panel regression method and logistic regression.

According to Anand Kumar T.S and others (2008), in their paper they examined the practical guidance to MFIs adopting the housing programme in addition to the existing line of micro-finance services and inputs about any market study, profiling the customers, product design, pricing of the product, affordability of the clients, income assessment, loan assessment, operational procedures, risk coping mechanisms and technical backup guidance. They found that MFIs should also ensure that housing micro-finance suits their strategy from institutional and financial perspectives. Singh, et.al, (2006) in his article described the housing sector by introducing various housing loan schemes for rural and urban population. The first attempt in this regard was the National Housing Policy (NHP), which was introduced in 1988. The National Housing Bank (NHB) was set up in 1988 as an apex institution for housing finance and a whollyowned subsidiary of Reserve Bank of India (RBI). The main objective of the bank is to promote and establish the housing financial institutions in the country as well as to provide refinance facilities to housing finance corporations and scheduled commercial banks. Moreover, for the salaried section, the tax rebates on housing loans have been introduced. The paper is based on the case study of LIC Housing Finance Ltd., which analyzes regionwise disbursements of individual house loans, their portfolio amounts and the defaults for the last ten years, i.e., from 1995-96 to 2004-05 by working out relevant ratios in terms of percentages and the compound annual growth rates. The authors have said that there is a need for designing the special schemes for financing of LIC Housing Finance Limited to meet its prime goal. 
According to Joydip Dasgupta (2015), in his paper he focused on Interest Rate Risk Management of HDFC which started off in 1977 as a new mortgage bank and operated S\&Lsin the first few years and raised retail deposits. This did not create much problem for the entity in the administered interest rate regime. The study offered a new paradigm shift in the financing pattern of HDFC for development of housing industry. The shift of financial strategy is suited to countershift risk profiles in the housing finance business in India and thus HDFC managed to create a niche in the industry. The author strongly felt that there is a need for extending liberal rate of interest to housing industry. The author strongly felt that there is a need for extending liberal rate of interest to housing industry.

\section{SCOPE OF THE STUDY}

The examination is cantered around the lodging advance borrowers of HDFC in the examination is for the most part planned to evaluate the view of borrowers with respect to the lodging account of HDFC. The different elements impacting mindfulness and fulfilment of borrowers are likewise examined.

\section{OBJECTIVES OF THE STUDY}

$>$ To break down the lodging fund in India as a rule

$>$ To look at the view of clients of HDFCL,

$>$ Identifying the main considerations deciding the home credit recipients

$>$ To recognize the issues in HDFC lodging finance

\section{RESEARCH METHODOLOGY}

The examination is cantered around the lodging advance borrowers of HDFC in the India. The investigation is for the most part planned to evaluate the view of borrowers with respect to the lodging fund of HDFC. The different components impacting mindfulness and fulfilment of borrowers are additionally considered.

\section{Limitations of the study}

1. This research study was time bound and only certain criteria were taken up for study.

2. 3. Some of the respondents might have been biased in their responses as it depends on their experience gained by them during processing of such loans.

\section{HOUSING FINANCE IN BRIEF}

Housing being one of the three essential needs of life dependably stays in the top needs of any individual, society and economy. As a person, an individual needs his own space and security, which can be given by the responsibility for house. The house is the essential unit of the general public. Home gives a stage to the family and the family is the most significant social foundation, which leaves its engraving on a person for entire life. Along these lines lodging merits critical consideration with regards to creating arrangements and systems for human improvement. Yet at the same time most of human people lives in ghettos, shanties and brief ratty sanctuaries in rustic regions. The deficiency of lodging is a major hindrance in the solid advancement of an individual and thus the general public, and the country. The issue of room, protection, security and sanitation prompts social, financial and ecological degeneration. The ceaseless conflict for space and house-possession prompts individual and social disorder, which is impeding for the general public and the economy. A creating country like India needs to concentrate more on lodging part to take into account the lodging needs of thriving populace and to quicken the monetary development. The Government of India had as of late made the advancement of the housing sector.

\section{HOUSING FINANCE IN INDIA}

In the initial 25 years of post-freedom, India has focused on rural improvement simply after the mechanical upset and the persistent moving of provincial populace to the urban regions, the requirement for advancement of lodging area has been accentuated. It is dependably a fantasy to claim a house anyway a lion's share of the populace does not have the required money related help to possess a house. Peering toward this as a chance, numerous organizations have decided on stretching out lodging credits not exclusively to support their main concerns yet additionally to decrease the overall interest and supply hole. The certified interest emerging out of the individual requirement for lodging, together with the present blast in the lodging segment it is good to go to give a stage to the lodging money organizations to cut out a bit of fortune. What stayed as a position of safety segment in India is all of a sudden seeing movement that is promising a splendid future. Out of India"s new lodging units, 20 percent are financed through the lodging financing organizations. With the hole between the required number of houses and the real, government recognized lodging division as a center and it is just with the convenient in mediation of the legislature that lodging fund has turned into a noteworthy industry in India. With the foundation of National Housing Bank, the administration has given the genuinely necessary lift to this division. At present out of 380 odd HFIs in India, 42 lodging fund organizations are enrolled with the National Housing Bank out of them 20 are legitimate for acknowledgment of open stores and remains are most certainly not. This number is going to increment sooner rather than later with the modern development. During the time some portion of the most recent decade, this division has seen a development of more than 30 percent and guarantees to develop a similar rate in the following couple of years. Perceiving the developing need of lodging account in India, the administration has stressed on lodging and lodging money in the ninth multi year intend to realize that there is a shortage of in excess of 20 mission house units. This is the first occasion when that India has underlined on the lodging segment 
STRUCTURE OF THE HOUSING FINANCE ORGANIZED HOUSING FINANCE SYSTEM IN INDIA

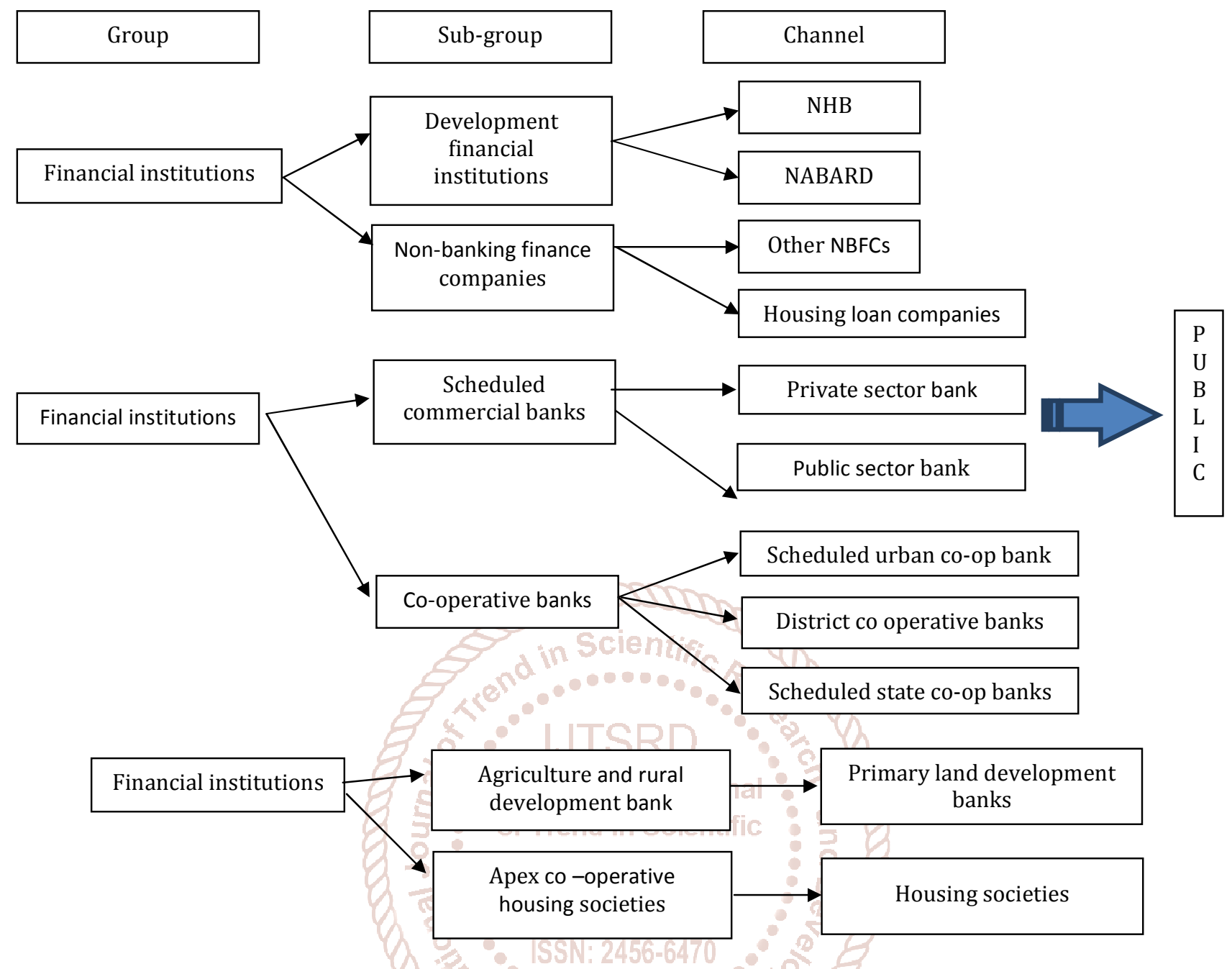

In 1985, the RBI made numerous proposals for advancement in the lodging money framework dependent on the report of Chakraborthy Committee. In 1987, HFC's revised the Insurance Act of India to permit the Life Insurance Corporation (LIC) and the General Insurance Corporation (GIC) to enter the lodging money business. 47 In 1988, the National Housing Bank was set up as an auxiliary of the RBI to go about as a peak administrative and limited time organization. In 1989, the RBI enabled Commercial banks to issue huge advances for lodging without forcing unbending limitations on financing cost or advance amount roof. National Housing Bank (NHB) was set up in July 1988 with the value support from the RBI and is expected to go about as the pinnacle foundation for organizing and building up the lodging money plans. Afterward, the UTI set up in 1989, a Housing Construction Investment support for direct interest in development tasks and land advancement. The section of LIC and GIC and numerous banks like SBI and Canara Bank through their backups has been begun to be another milestone in the advancement of lodging Impact. The setting up of National Housing Bank as a completely possessed backup of the RBI, and as a summit foundation was the zenith of the satisfaction of a long late need of the lodging money industry in India. The framework has additionally been portrayed by the rise of a few specific money related foundations, which have extensively reinforced the association of the lodging fund framework in the nation. In
1990 's the pace set in the previous decades was conveyed forward. Numerous HFCs were set up under the headings of the NHB. The procedure of progression secured the retail lodging account segment significantly.

\section{TYPES OF HOUSING FINANCE}

Various kinds of home loans are available in India. They are described below:

\section{$>$ Home purchase loa}

These are the basic home loans for the purchase of a new home. These loans are given for purchase of a new or already built flat \bungalow $\backslash$ row-house.

\section{$>$ Home improvement loan}

These loans are given for implementing repair works and renovations in home that has alredy been purchased by the customer. It may be requested for external works like structural repairs, waterproofing or internal works like tiling and flooring, plumbing, electrical work, painting etc.

\section{$>$ Home construction loan}

These loans are available for the construction of a new home. The documents required by the banks or bank for granting customer a home construction loans are slightly different from the home purchase loans. Depending upon the fact that when customer bought the 
land, the lending party would or would not include the land cost as a component, to value the total cost of the property.

\section{$>$ Home extension loan}

Home extension loans are given for expanding or extending an existing home. For example addition of an extra room, ect. For this kind of loan, customer needs to have requisite approvals from the relevant municipal corporation.

\section{$>$ Land purchase loans}

Land purchase loans are available for purchase of land for both home construction or investment purposes. Therefore, customer can be granted this loan even if customer is not planning to construct any building on it in the near future. however, customer has to complete construction within tenure of three years on the same land.

\section{$>$ Bridge loan}

Bridge loans are designed for people who wish to sell the existing home and purchase another. The bridge loan helps finance the new home, until a buyer is found for the old home.

\section{$>$ Balance transfer}

Balance transfer loans help customer to pay off an existing home loan and avail the option of a loan with a lower rate of interest. Customer can transfer the balance of the existing home loan to either the same banks or any another banks.

\section{$>$ Stamp duty amount}

These loans are sanctioned to pay the stamp duty amount that needs to be paid on the purchase of property.

\section{$>$ NRI home loan}

This is a special home loan scheme for the non-resident Indians (NRI) who wish to build or buy a home or land property India, they are offered attractive housing finance plans with suitable reimbursement options by many banks in the country.

\section{SCHEME OF HOUSING LOANS}

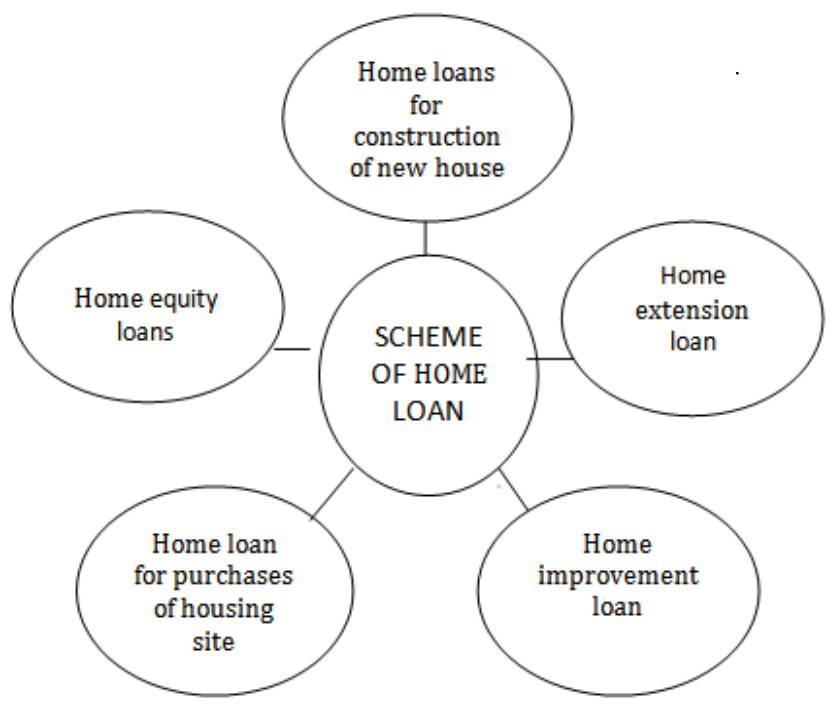

\section{IMPORTANCE OF HOUSING LOAN}

$>$ The need for home loans arises not because property prices are heading upwards all the time but because home loans make great sense from a long -term savings perspective. Not only are home loans a handy tool for the common man to own a roof over his head but they also help save money in the long run.

$>$ With skyrocketing real estate prices, people are increasingly opting for housing loans to acquire their dream home. Interest rates are coming down all the time and the banks and the housing finance companies are literally falling over each other to lure the prospective home-seekers.

$>$ Notwithstanding the tax breaks and generous lending rates, a lot of people still cannot arrange resources for the down-payment, which comes out to be at least 15 per cent of the property value. Taking cognizance of the situation, banks are coming up with home loan products called "zero down payment loan" where in 100 per cent funding is provided for select properties. These lucrative offers are other major reasons for why people are opting for loans.

Even if one can afford to buy a home with one's own money, home loans should be availed because they act as good savings instrument. According to industry estimates, the long term average return in investing in a home is about $20 \%$ p.a while the average cost of borrowing funds in the market today is about $7 \%$ p.a (considering all tax breaks).

For salaried employees, housing loans are the best way to avail of tax benefits. Many people simply go for the home loans in order to avail these benefits. Interest payments up to 2.0 lash on housing loans are deductible from the taxable income and there is a further deduction of taxable income maximum up to 1.5 lakh against repayment of principal portion per annum. In case a person stays in a rented house, the cost of the loan will be nearly zero percent since he will be saving a decent amount on rent.

\section{ADVANTAGES OF HOME LOANS}

The various benefits of home loans arising to the customers are: Help in owning a home

$>$ Tax benefits of home loans

$>$ Attractive interest rates

$>$ Long term loan

$>$ Repayment schedule on the basis of Earning

$>$ Capacity of the borrower

\section{DISADVANTAGES OF HOME LOANS}

The main disadvantages of home loans are high lightened as below:

High processing fee

$>$ Delay in processing

$>$ Fluctuating interest rate

$>$ Problems in disbursement

The above mentioned disadvantages or limitations can be removed by providing good, prompt and efficient services to the customers. 


\section{CONCLUSIONS}

The housing finance business in India is under rapid reforms since the inception of NHB. The fundamental areas of housing business are rapidly observing rapid reforms. The structural reforms that system initiated were giving results slowly. But the market demand and supply are still with gaps.

\section{REFERENCES BOOKS}

[1] Indian Institute of Banking \& Finance

[2] Principles of Banking, Indian Institute of Banking and Finance
[3] magazines on home loans.

\section{WEBLIOGRAPHY}

$>$ www.google.com

$>$ www.slideshare.com

$>$ www.shodhganga.com

\section{NEWS PAPERS}

$>$ Economic times

$>$ Time of India

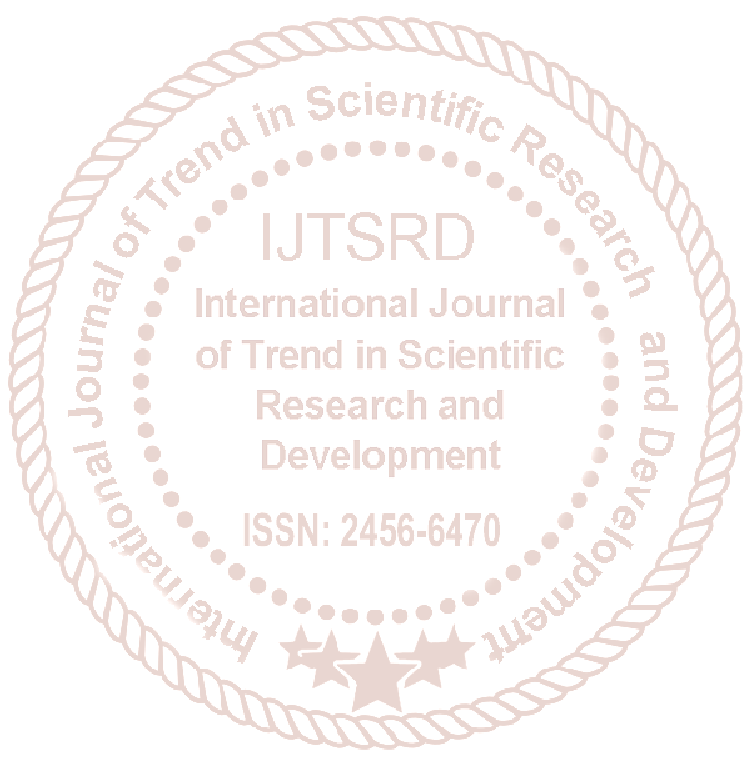

